\title{
Family history and DNA analysis in patients with suspected Huntington's disease
}

S Siesling, M Vegter-van de Vlis, M Losekoot, R D M Belfroid, J A Maat-Kievit, H P H Kremer, R A C Roos

\begin{abstract}
Objectives-Until recently a definite diagnosis of Huntington's disease could be made by a combination of clinical findings, a positive family history, and pathological confirmation. Prevalence data are based on these criteria. After finding the gene and its pathogenic mutation direct diagnostic confirmation became available. The aim of this study was to determine to what extent the direct assessment of CAG repeat length has allowed the diagnoses of additional patients, with atypical psychiatric or neurological disease, or those without a family history, that could otherwise not be diagnosed using traditional criteria.
\end{abstract}

Patients and methods-From all 191 referred patients suspected of having Huntington's disease between July 1993 and January 1996 CAG repeat length was determined and the family history was reviewed in the Leiden roster. After a retrospective search the patients were subdivided in positive, negative, suspect, and unknown family histories. Patients with an expanded repeat $(>35)$ were finally diagnosed as having Huntington's disease. The family history was compared with the repeat length and the clinical features.

Results-Clinical information was obtained for 172 patients. Of these, 126 patients had an expanded repeat, 77 had a positive, eight a negative, 40 a suspect, and one an unknown family history. Of the 44 patients with a normal repeat length four had a positive family history. Of the two patients with an intermediate repeat (between 30-36 repeats), one with a negative family history received a clinical diagnosis of Gilles de la Tourette's syndrome. The other had an unknown family history. Conclusion-Despite verification of the family history through the Leiden roster, many more patients and families could be diagnosed with the new approach than would have been possible with the traditional criteria. Because prevalence studies have been based on this type of information, the data suggest an underestimation of the prevalence of Huntington's disease in the community of $14 \%$. (F Neurol Neurosurg Psychiatry 2000;69:54-59)

Keywords: Huntington's disease; prevalence; sporadic; CAG repeat

Until recently, the diagnosis of Huntington's disease could only be made in the presence of progressive choreic movements, behavioural disturbances, dementia, and a positive family history. The confirmation of the family diagnosis was based on the neuropathological findings in affected family members. Using these criteria various investigators generated prevalence data of ethnic populations world wide that yielded prevalence rates between 3/100 000 and 7/100 000 people of western European descent. ${ }^{1}$ Crucial for the diagnosis was the elucidation of a family history consistent with an autosomal dominant inheritance.

After the discovery of the gene and its pathogenic mutation in $1993^{2}$ a definitive diagnosis could be made in people with specific neurological signs, and reliable presymptomatic testing could be offered to those at risk. Moreover, the assessment of CAG repeat length allowed the identification of patients with atypical psychiatric or neurological disease, or those without a family history, as having Huntington's disease.

In The Netherlands, DNA testing for Huntington's disease as a diagnostic and presymptomatic tool for clinical use was centralised at the Department of Clinical Genetics in Leiden until 1996. Also, at this department a centralised roster of Huntington's disease families was kept, which was started in the mid-1930s. Before CAG assessment the roster had allowed clinicians all over the country to acquire information, that was otherwise unavailable, about the status of family members of patients suspected of Huntington's disease. It was considered that the use of such a roster had allowed near complete identification of Huntington's disease families in The Netherlands.

The aim of this retrospective study was to determine to what extent the direct assessment of CAG repeat length has allowed us to diagnose additional patients and families that could otherwise not be diagnosed with traditional criteria.

\section{Patients and methods}

Between July 1993 and January 1996, 191 requests were submitted from all over the country by neurologists (157 patients), psychiatrists (16 patients), and clinical geneticists (18 patients) to determine the presence or absence of an expanded CAG repeat in the IT15 gene because of a clinical syndrome of involuntary movements, or psychiatric disorders. The number of requests in 1993, 1994, and 1995 was 31, 99, and 61 respectively. To prevent presymptomatic testing, which requires specific counselling, the referring physicians had to describe the main symptoms on the request form. 
Because the information about the clinical features and the family history was not always described in sufficient detail on the form, further information was obtained retrospectively from the referring physicians, who obtained informed consent from the patients (or relatives).

For all patients the family history was checked with the Leiden roster. This roster contains pedigree information on over 3000 persons, extending back to the 18th century, from Huntington's disease kindreds in the Netherlands. ${ }^{3}$ Since the mid-1930s information on the pedigrees is obtained by families and is extended using parish records, municipal registers, and national archives. The roster is in total compliance with recent Dutch legislation for individual privacy and protection of sensitive medical data. A family history was considered to be positive when at least one other pathologically or genetically established patient with Huntington's disease was known in the family. A family history was considered to be negative when no other siblings had any signs or symptoms of Huntington's disease, and both parents were alive and healthy or lived without neurological or psychiatric disorders over the age of 65 years. A family history was considered to be suspect when one parent had an ambiguous history or had died before the age of 65 years, or when the family history disclosed a neurological (parkinsonism), or psychiatric disorder, or suicide. If no information could be obtained the family history was considered to be unknown. Age at onset was defined as the age at which the first appearance of involuntary movements, behavioural disorders, or character changes was seen by the patient, the family, or the physician.

The family history was compared with the length of the CAG repeat. This was determined in DNA isolated from venous blood with a

Table 1 Family history of the 172 patients and the $C A G$ repeat

\begin{tabular}{lrrrr}
\hline & \multicolumn{5}{c}{ CAG repeat length } \\
\cline { 2 - 5 } Family history & $>35$ & $<30$ & Intermediate & Total \\
\hline Positive & 77 & 4 & & 81 \\
Negative & 8 & 21 & 1 & 30 \\
Suspect & 40 & 17 & & 57 \\
Unknown & 1 & 2 & 1 & 4 \\
Total & 126 & 44 & 2 & 172 \\
\hline
\end{tabular}

polymerase chain reaction assay as described previously. ${ }^{4}$ A repeat over 35 was considered as expanded and diagnostic of Huntington's disease. ${ }^{56}$ Of the patients in whom a discrepancy between family history and CAG repeat length was found, a detailed retrospective clinical description was extracted from the records.

\section{STATISTICAL ANALYSIS}

To assess differences in the length of the CAG repeats, the age at onset, and the durations of illness of the patients in data from the four different family history groups were analysed by ANOVA with Student's $t$ tests for post hoc comparisons. The relation between the repeat length and the age at onset was assessed with the Pearson correlation coefficient. Data were analysed using the statistical package for social sciences (SPSS). p Values $<0.05$ were considered to be statistically significant.

\section{Results}

Of the original 191 referred requests three could not be contacted by their referring physician to obtain informed consent and three patients refused to participate. For 13 patients, not enough clinical details could be obtained. Therefore, 172 patients were included in the further analysis (table 1).

POSITIVE FAMILY HISTORY

Of the 81 patients with a positive family history in the roster, $77(95 \%)$ received a final diagnosis of Huntington's disease (mean repeat length 45.7, range 40-59). The remaining four patients had a normal repeat length (table 1). The positive family history was well known by the referring physicians before submission. Of these four with a normal repeat length, patient 1 (male) had an affected father and sister. Clinically, he had chorea combined with a behavioural disorder and dementia as presenting signs. During the course of the disease the patient developed rigidity soon after onset. No neuroleptic drugs were used. Dystonia, mainly seen in the upper limbs, was progressive. On CT cortical atrophy and atrophy of the caudate nucleus was present. No final diagnosis could be made (table 2). The other three patients had an atypical presentation of psychiatric symptoms without choreic movements (table 2, patients 2-4). Patient 3 was addicted to

Table 2 Characteristics of seven patients with a positive family history and discrepancy in prior clinical diagnosis and final diagnosis. Four patients had Huntington's disease (HD) as prior clinical diagnosis and a normal repeat. Three patients had a prior clinical diagnosis different from $H D$ and an expanded repeat, leading to $H D$ as final diagnosis

\begin{tabular}{|c|c|c|c|c|c|c|c|c|c|c|}
\hline Patient & $\begin{array}{l}\text { Age at } \\
\text { onset } \\
(y)\end{array}$ & First symptom & $\begin{array}{l}\text { Prior clinical } \\
\text { diagnosis }\end{array}$ & $\begin{array}{l}\text { Duration } \\
\text { of illness } \\
\text { (y) }\end{array}$ & Chorea & $\begin{array}{l}\text { Psychiatric } \\
\text { disorders }\end{array}$ & Dementia & $C T$ & $\begin{array}{l}\text { CAG } \\
\text { repeat } \\
\text { length }\end{array}$ & Diagnosis \\
\hline 1 & 38 & Chorea/behavioural disorders/dementia & HD suspect & 7 & $\begin{array}{l}- \\
\text { Rigidity }\end{array}$ & - & + & a & $18 / 19$ & $\begin{array}{l}\text { Progressive } \\
\text { degeneration, no HD }\end{array}$ \\
\hline 2 & 45 & $\begin{array}{l}\text { "Hot standing on firm ground"/ } \\
\text { depression/motor impersistance }\end{array}$ & HD suspect & 5 & - & + & - & $\mathrm{n}$ & $19 / 20$ & No HD \\
\hline 3 & 32 & Behavioural disorders & HD suspect & 1 & - & + & - & - & $16 / 18$ & No HD \\
\hline 4 & 41 & Behavioural disorders & HD suspect & 9 & - & + & - & - & $15 / 17$ & $\begin{array}{l}\text { Depressive regressive } \\
\text { syndrome }\end{array}$ \\
\hline 5 & 59 & Chorea/behavioural disorders & $\begin{array}{l}\text { Chorea of } \\
\text { unknown cause }\end{array}$ & 11 & + & + & - & a & $16 / 42$ & HD \\
\hline 6 & 66 & Chorea & Choreoathetosis & 7 & + & - & - & a & $18 / 43$ & $\mathrm{HD}$ \\
\hline 7 & 32 & Chorea/dystonia & $\begin{array}{l}\text { Chorea of } \\
\text { unknown cause }\end{array}$ & 7 & + & - & - & $\mathrm{n}$ & $18 / 52$ & $\mathrm{HD}$ \\
\hline
\end{tabular}


Table 3 Characteristics of 30 patients (8-37) with a negative family history. Eigth patients had an expanded repeat and had HD as final diagnosis. One patient had an intermediate repeat

\begin{tabular}{|c|c|c|c|c|c|c|c|c|c|c|}
\hline Patient & $\begin{array}{l}\text { Age at } \\
\text { onset } \\
(y)\end{array}$ & First symptom & Prior clinical diagnosis & $\begin{array}{l}\text { Duration } \\
\text { of illness } \\
(y)\end{array}$ & Chorea & $\begin{array}{l}\text { Psychiatric } \\
\text { disorders }\end{array}$ & Dementia & $C T$ & $\begin{array}{l}\text { CAG } \\
\text { repeat } \\
\text { length }\end{array}$ & Final diagnosis \\
\hline 8 & 40 & $\begin{array}{l}\text { Chorea/behavioural } \\
\text { disorders }\end{array}$ & Chorea of unknown cause & 2 & + & + & + & $\mathrm{n}$ & $24 / 44$ & HD \\
\hline 9 & 39 & Chorea & Chorea of unknown cause & 14 & + & + & + & - & $22 / 44$ & HD \\
\hline 10 & 23 & Psychotic/insecure walking & Chorea of unknown cause & 15 & - & + & - & - & $18 / 47$ & HD \\
\hline 11 & 52 & Chorea & Chorea of unknown cause & 10 & + & + & - & - & $17 / 44$ & $\mathrm{HD}$ \\
\hline 12 & 41 & $\begin{array}{l}\text { Chorea/behavioural/ } \\
\text { character disorders }\end{array}$ & Chorea of unknown cause & 7 & - & + & - & $\mathrm{a}$ & $19 / 45$ & HD \\
\hline 13 & 50 & $\begin{array}{l}\text { Chorea/behavioural } \\
\text { disorders }\end{array}$ & Chorea of unknown cause & 5 & + & + & - & - & $17 / 44$ & HD \\
\hline 14 & 54 & Chorea & HD suspect & 14 & + & + & - & a & $22 / 44$ & HD \\
\hline 15 & 53 & $\begin{array}{l}\text { Chorea/behavioural } \\
\text { disorders }\end{array}$ & HD suspect & 5 & + & + & - & - & $18 / 42$ & HD \\
\hline 16 & 31 & $\begin{array}{l}\text { Behavioural } \\
\text { disorders/psychotic/tics }\end{array}$ & HD suspect & 6 & + & + & - & $\mathrm{n}$ & $22 / 32$ & Gilles de la Tourette \\
\hline 17 & 72 & Chorea & Chorea of unknown cause & 2 & + & - & - & - & $20 / 28$ & $\begin{array}{l}\text { Steele-Richardson- } \\
\text { Olsewski }\end{array}$ \\
\hline 18 & 39 & Chorea & Chorea of unknown cause & 7 & + & - & - & - & $16 / 16$ & Benign chorea \\
\hline 19 & 1 & Chorea & Chorea of unknown cause & 7 & + & - & - & - & $16 / 17$ & Benign chorea \\
\hline 20 & 62 & Chorea/insecure walking & Chorea of unknown cause & 4 & - & + & + & $\mathrm{n}$ & $20 / 21$ & $\begin{array}{l}\text { Chorea of unknown } \\
\text { cause }\end{array}$ \\
\hline 21 & 65 & Mandibular dystonia & chorea of unknown cause & 5 & + & - & - & - & $19 / 23$ & $\begin{array}{l}\text { Meige/tardive } \\
\text { dyskinesia }\end{array}$ \\
\hline 22 & 20 & Hemichorea & Chorea of unknown cause & 14 & + & - & - & $\mathrm{n}$ & $17 / 17$ & No symptoms \\
\hline 23 & 65 & Chorea/strange thoughts & Chorea of unknown cause & 8 & + & - & + & $\mathrm{n}$ & $17 / 19$ & Vascular \\
\hline 24 & 49 & Chorea & Chorea of unknown cause & 3 & + & + & - & - & $17 / 17$ & $\begin{array}{l}\text { Neuroleptic induced } \\
\text { chorea }\end{array}$ \\
\hline 25 & 26 & $\begin{array}{l}\text { Chorea/disturbance of } \\
\text { coordination }\end{array}$ & Chorea of unknown cause & 15 & + & - & - & $\mathrm{n}$ & $17 / 18$ & $\begin{array}{l}\text { Chorea ataxia/higher } \\
\text { function loss }\end{array}$ \\
\hline 26 & 66 & Chorea & HD suspect & 12 & + & + & + & a & $18 / 20$ & - \\
\hline 27 & 30 & No balance & HD suspect & 14 & - & + & + & a & $17 / 20$ & ADL \\
\hline 28 & 40 & $\begin{array}{l}\text { Chorea/no } \\
\text { balance/vomiting }\end{array}$ & HD suspect & 5 & + & - & - & $\mathrm{n}$ & $18 / 19$ & - \\
\hline 29 & 52 & $\begin{array}{l}\text { Chorea/behavioural } \\
\text { disorders }\end{array}$ & HD suspect & 3 & + & + & + & - & $12 / 15$ & Progressive dementia \\
\hline 30 & 28 & $\begin{array}{l}\text { Dysarthria/nervous } \\
\text { face/CVA }\end{array}$ & Organic psychosyndrome & 7 & - & - & - & - & $19 / 21$ & $\begin{array}{l}\text { CADASIL/subcortical } \\
\text { infarct }\end{array}$ \\
\hline 31 & 5 & Chorea/low intellect & $\begin{array}{l}\text { Non-progressive (non-)hereditary } \\
\text { chorea }\end{array}$ & 42 & + & - & - & $\mathrm{n}$ & $15 / 24$ & - \\
\hline 32 & 4 & Chorea/tics/swearing & Gilles de la Tourette & 16 & + & + & - & - & $15 / 17$ & Gilles de la Tourette \\
\hline 33 & 75 & Chorea & Morbus Bechterew & 1 & + & - & - & - & $18 / 21$ & Chorea during illness \\
\hline 34 & 64 & Chorea/insecure walking & $\begin{array}{l}\text { Torsion dystonia/chorea of } \\
\text { unknown cause }\end{array}$ & 8 & + & - & - & $\mathrm{n}$ & $20 / 22$ & - \\
\hline 35 & - & $\begin{array}{l}\text { Behavioural/character } \\
\text { disorders }\end{array}$ & Not clear/oligofrenia & - & + & + & - & a & $17 / 20$ & $\begin{array}{l}\text { Chorea of unknown } \\
\text { cause with } \\
\text { oligophrenia+dementia }\end{array}$ \\
\hline 36 & 45 & Chorea & $\begin{array}{l}\text { StVitus dance/induced by } \\
\text { neuroleptica }\end{array}$ & 20 & + & - & - & $\mathrm{n}$ & $17 / 22$ & $\begin{array}{l}\text { Remainder of StVitus } \\
\text { dance }\end{array}$ \\
\hline 37 & 34 & Strength loss & $\begin{array}{l}\text { Faciohumeroscapular dystrophy } \\
\text { (Landouzy-Dejerine) }\end{array}$ & 27 & - & + & + & - & $20 / 24$ & Landouzy-Dejerine \\
\hline
\end{tabular}

+=Observed; $-=$ not observed; $\mathrm{a}=$ abnormalities on CT; $\mathrm{n}=$ no CT.

cocaine. The other two patients did not use medication.

Three patients with an expanded repeat length had a positive family history in the roster, but were submitted by the referring physicians as having negative (two patients) or unknown (one patient) family history. Clinically, these patients all had clear symptoms of Huntington's disease (table 2).

\section{NEGATIVE FAMILY HISTORY}

The clinical details of the 30 patients with a negative family history are described in table 3 (patients 8-37). Eight (27\%) had Huntington's disease as the final diagnosis (mean repeat length 44.5, range 42-47) (table 3; patients $8-15)$. This contributed $6.3 \%$ of the 126 patients with an expanded repeat. Of the eight patients with an expanded repeat, six (patients 8-13) had chorea of unknown cause, and two (patients 14 and 15) had Huntington's disease suspected as a prior clinical diagnosis. Presenting signs were chorea $(n=3)$, a combination of chorea and behavioural disorder $(n=4)$, and psychosis with gait problems $(n=1)$. During the disease all eight patients had severe psychiatric disorders as their main clinical sign.

One patient (male, patient 16) had an intermediate repeat of $22 / 32$ CAG repeats. Clinically, this patient presented with a behavioural disorder, mainly aggressive outbursts, psychosis, and tics as first symptoms. In the course of the disease he developed chorea. After CAG repeat determination his clinician considered Gilles de la Tourette's syndrome as the most likely diagnosis (table 3 ).

\section{SUSPECT FAMILY HISTORY}

Of the 57 patients with a suspect family history, of whom the roster was unable to provide a positive family history, 40 (70\%) had Huntington's disease as the final diagnosis (mean repeat length 43.7, range 39-66) (table 1). In 17 patients the parents had died before the age of 65 years and in two patients the biological father remained unknown. In 35 patients one parent was suspected of having Huntington's disease. The suspicion was based on restless movements $(n=14)$, parkinsonism $(n=4)$, psychiatric symptoms $(n=10)$, and dementia 
$(n=7)$. A member in the families of three patients had committed suicide.

During the disease, all the 40 patients with an expanded repeat developed chorea. In 25 patients this was combined with dementia, in 30 with a psychiatric disorder, and in 15 with dysarthria. In the 17 patients with normal repeat length 15 developed chorea, which was combined with dementia in two patients. Eight patients had psychiatric disorder only.

UNKNOWN FAMILY HISTORY

Of the four patients with a family history unknown to the referring physician, and whose family history could not be identified in the roster, one had an expanded repeat (16/40; table 1). This patient had choreic movements and dysarthria and was diagnosed as suspected of having Huntington's disease. Of the remaining three patients with an unknown family history two patients were submitted to exclude Huntington's disease. In one patient the final diagnosis of tardive dyskinesia and in the other a diagnosis of probable multiple sclerosis was made. One patient (female) who was born outside The Netherlands, had an intermediate repeat length of 17/31 CAG repeats (table 1). She clinically showed chorea as an isolated sign and was submitted with chorea of unknown cause as prior clinical diagnosis. After the repeat determination no final diagnosis was established.

COMPARISON OF THE DEFINITE FAMILY HISTORY GROUPS

The unknown family history group was too small to take into account for the statistical analysis, thus lengths of the expanded repeats in the three other family history groups were compared and a significant longer repeat was disclosed in the patients with a positive family history than in patients with a suspect family history $(p<0.05)$. The mean age at onset in the patients with Huntington's disease with an expanded repeat and a positive family history was 40.1 years ( $n=74$, range $4-67$ years), which was significantly lower than in the patients with a suspect family history $(n=34$, mean age at onset 50.5 years, range $22-69$ years, $\mathrm{p}<0.01$ ). The mean age at onset in the patients with a negative family history was 44.0 years $(n=8$, range 23-54 years), which did not differ from the other two CAG expanded groups. The duration of illness did not differ between the three groups.

A significant inverse relation was found between the repeat length and the age at onset in the three groups (positive family history -0.69 , negative family history -0.82 , and suspect family history -0.67 , all $\mathrm{p}<0.01$ ).

\section{Discussion}

Before the discovery of the Huntington's disease gene and its pathogenic mutation, a diagnosis of Huntington's disease was based on clinical features, family history, and pathological confirmation. This family history could be verified through a roster, such as the one in Leiden. Such a roster may provide the best information possible to assess family details for clinical use, although from an epidemiological and research point of view, the information would be incomplete.

In the literature, over $99 \%$ of patients with a clinical diagnosis of Huntington's disease and a positive family history have been found to have an expanded CAG repeat. ${ }^{27-10}$ In our study this percentage was $95 \%$, which is comparable with the findings of Sanchez et $a l^{11}$ and Zülke et al. ${ }^{12}$ In retrospect, the $5 \%$ represent three atypical patients and one possible phenocopy. The three atypical patients were diagnosed as having Huntington's disease with a positive family history (table 2, patients $2-4$ ), but the diagnoses made in these clinically atypical patients may have been prejudiced by the positive family history. The patient with clear signs of Huntington's disease could represent a phenocopy (table 2 , patient 1 ). A few patients in a similar situation have been described previously. Andrew et $a l^{10}$ found in a cohort of 1022 patients, seven patients $(0.7 \%)$ with a positive family misdiagnosed, and 12 patients $(1.2 \%)$ to be possible phenocopies. Eight of these 12 patients $(0.8 \%)$ had a positive family history, which is comparable with our results.

Eight of 30 patients with a negative family history $(27 \%)$ had an expanded repeat, which is somewhat lower than the $40 \%$ described by Mandich et $a l,{ }^{13}$ who used the same definitions for a negative family history as we did.

The proportion of those with an expanded repeat and a suspect family history was higher than the proportion of those with an expanded repeat and a negative family history. Of those with a suspect family history $(n=57), 40$ persons $(70 \%)$, had an expanded repeat. This proportion is similar to the $65 \%$ of Davis et $a l^{14}$ and $85.7 \%$ of Mandich et al. ${ }^{13}$ All these patients had clinically obvious and typical Huntington's disease features.

This remarkably high number of patients with an expanded CAG repeat and an uninformative family history, which we found in this study, either because of a negative $(n=8)$, a suspect $(n=40)$, or an unknown family history $(n=1)$ may be explained in several different ways. The sporadic patient could represent a de novo CAG expansion, which may occur in about $3 \%$ of the affected patients ${ }^{15}$ as a result of expansion of "intermediate alleles" usually through the male germline. ${ }^{16-19}$ Several investigators expect the appearance of patients with new mutations to be higher. ${ }^{20-23}$ In our study we could not obtain DNA from the parents of the eight patients with sporadic Huntington's disease because they were deceased $(n=4)$ or no family contact existed $(n=4)$. If all eight sporadic patients were regarded as new mutations this study would suggest an upper limit to the mutation rate of $6.3 \%(8 / 126)$.

Non-paternity, which could not be excluded in this study, could have been another explanation for a few "sporadic" patients. The incidence of non-paternity in the general population has been estimated to be about $5 \%{ }^{24}$

A third explanation may be the late onset of clinical signs in the parents with anticipation in 
the probands. The risk of being affected after the age of 50 is estimated to lie between $10 \%$ and $25 \%$, which is probably an underestimate as death may occur from other causes before the onset of Huntington's disease. ${ }^{25}$ Late onset disease is usually milder in presentation with milder chorea and less cognitive decline. ${ }^{26}{ }^{27} \mathrm{It}$ could easily have been overlooked or misdiagnosed, thus obscuring the family history. The longer repeat length would explain the earlier onset in the children. This could explain the shorter repeat length and higher age at onset in the patients with a suspect family history compared with the patients with a positive family history. Moreover, first signs in a patient with a positive family will be recognised earlier, resulting in a lower age at onset. Another explanation for the apparently healthy survival in old age of the parents could be due to an incomplete penetrance of the CAG mutation (range 36-39), which may rarely occur in those without any clinical or pathological manifestation of the disease. $.^{23} 28-30$

Two patients with neurological abnormalities had repeat lengths in the intermediate range (17/31 and 22/32 respectively). Clinically, one had chorea and the other chorea combined with psychiatric disorders and tics as atypical features. The question arises whether these are patients with Huntington's disease with an extremely low repeat size. In the literature eight patients with CAG sizes within the range of 30 to 37 repeats have been described with clinical features. ${ }^{82} 3031$ Hanning et $a l^{23}$ found repeat lengths between 30-39 repeats in 41 out of 2592 patients $(1.6 \%)$. Spector et a ${ }^{30}$ found five out of 181 patients $(2.8 \%)$ to have repeats in this range. In both studies the number of patients with repeat lengths between 30 and 36 repeats was not described.

The intermediate sized alleles could represent the tail of the normal range. Extrapolating the correlation of the age at onset and the CAG repeat length, ${ }^{32}$ repeat lengths in this range would be associated with an extremely late age at onset. However, Andrew et $a l^{\beta 2}$ determined at the lower end of the range of CAG repeat lengths very broad confidence limits for age at onset prediction. Thus, CAG repeat lengths between 30 and 36 repeats could give a disease phenotype given a long enough survival.

This study again illustrates the contribution of determination of CAG repeat length to the diagnosis of Huntington's disease in patients with a suspect or negative family history as well as in patients with a positive family history. Despite verification and extension of the family history through the Leiden roster more than one third of the patients could not be linked to a known family. Because prevalence studies traditionally have been based on these types of criteria, the number of patients with an expanded repeat and a negative, suspect, or unknown family history implies an underestimate of the prevalence of Huntington's disease in the community. Because not all patients with definite clinical Huntington's disease and a positive family history have applied for CAG repeat determination an estimate of the actual prevalence can only be made by extrapolation of the percentage of patients with Huntington's disease with positive family history applied by the department of neurology of the Leiden University Medical Centre. Sixty four patients were applied for CAG repeat determination by the department of neurology of the Leiden University Medical Centre, of whom 35 patients had a positive family history and expanded CAG repeat.

During the period of this study the number of patients with Huntington's disease with a known family history in Leiden was 159 . Thus $22 \%$ of these patients with a positive family history study have been sent for determination of the CAG repeat. Under the assumption that all referring physicians sent the same percentage of their patients with Huntington's disease with a known family history for CAG repeat determination the 77 patients with a positive family history and an expanded repeat of this study should be $22 \%$ of the total, which is 350 patients.

Assuming that all 49 patients with Huntington's disease (with an expanded CAG repeat) with a suspect, negative, or unknown family history have been applied for CAG repeat determination the prevalence increases with $14 \%(49 / 350)$. Subtle aspects of the clinical examination, knowledge about the family history, and the physician's experience with Huntington's disease all influence the need to obtain genetic analysis to confirm or exclude the disease.

We are very grateful to: Drs KD Beintema, GJP Bloemen, WA Bos, ERP Brunt, JM Cobben, CME de Die-Smulders, PA van Doorn, JG Eerenberg, PMM van Erven, PhD, Jde Graaf, MYC Gruijters, J Haan, HMG de Haan, G Hageman, DJ Heersema, GDM van Hellemondt, LI Hertzberger, LJMA van Hooff, A GDM van Hellemondt, LI Hertzberger, LJMA van Hooff, A
Hovestadt, FA Jongbloed, PAM Koch, PJ Koeler, PLM de Kort, Hovestadt, FA Jongbloed, PAM Koch, PJ Koeler, PLM de Kort, JJ Korten, L Liem, WHG Liewens, M Lucas, Professor MF
Niermeijer, C Oppelaar, RAF Pasanea, JG Post, J Posthuma, R Schaafstra, RLLA Schellens, J Schillemans, RTh Schoenmaker, Schaafstra, RLLA Schellens, J Schillemans, RTh Schoenmaker, HAW Sinnige, PO Slaats, CJ Sleeboom-van Raay, A van Spreeken, MEM Strik, JC van Swieten, TJ Tacke, HJ Troelstra, GJM Walstra, MJvan Weers, ECMJ Wolters, and others for participating in this study. Professors D Lindhout, and MF Niermeijer, are thanked for their advice. $M$ Vergeer is thanked for his help in obtaining the first clinical data. Professsor JP Vandenbroucke of the department of Clinical Epidemiology is thanked for his critical comment We are grateful for the financial support of the "Nederlandse Chorea van Huntington Stichting".

1 Harper PS, Houlihan GD, Lesley Jones A, et al. Huntington's Disease. London: Saunders, 1996.

2 Huntington's Disease Collaborative Research Group. A novel gene containing a trinucleotide repeat that is expanded in Huntington's disease chromosomes. Cell 1993;72:971-83.

3 Roos RA, Vegter-van der Vlis M, Hermans J, et al. Age at onset in Huntington's disease: effect of line of inheritance and patient's sex. F Med Genet 1991;28:515-19.

4 De Rooij KE, De Koning Gans PA, Skraastad MI, et al. Dynamic mutation in Dutch Huntington's disease patients: increased paternal repeat instability extending to within the normal size range. $\mathcal{F}$ Med Genet 1993;30:996-1002.

5 Rubinsztein DC, Leggo J, Coles R, et al. Phenotypic characterization of individuals with 30-40 CAG repeats in the Huntington disease (HD) gene reveals HD cases with 36 repeats and apparently normal elderly individuals with 36-39 repeats. Am f Hum Genet 1996;59:16-22.

6 Barron LH, Warner JP, Porteous M, et al. A study of the Huntington's disease associated trinucleotide repeat in the Scottish population. F Med Genet 1993;30:1003-7.

7 Duyao M, Ambrose C, Myers R, et al. Trinucleotide repeat length instability and age of onset in Huntington's disease [comments]. Nat Genet 1993;4:387-92.

8 Snell RG, MacMillan JC, Cheadle JP, et al. Relationship between trinucleotide repeat expansion and phenotypic

9 Kremer B, Goldberg P, Andrew SE, et al. A worldwide study of the Huntington's disease mutation. The sensitivity and specificity of measuring CAG repeats [comments]. N Engl f Med 1994;330:1401-06. 
10 Andrew SE, Goldberg YP, Kremer B, et al. Huntington disease without CAG expansion: phenocopies or errors in

11 Sanchez A, Castellvi-Bel S, Mila M, et al. Huntington's disease: confirmation of diagnosis and presymptomatic testing in Spanish families by genetic analysis. $\mathcal{F}$ Neuro Neurosurg Psychiatry 1996;61:625-7.

12 Zuhlke C, Riess O, Schroder K, et al. Expansion of the (CAG)n repeat causing Huntington's disease in 352 patients of German origin. Hum Mol Genet 1993;2:1467-9.

13 Mandich P, Dimaria E, Bellone E, et al. Molecular analysis of the IT15 gene in patients with apparently sporadic Huntington's disease. Eur Neurol 1996;36:348-52.

14 Davis MB, Bateman D, Quinn NP, et al. Mutation analysis in patients with possible but apparently sporadic Huntington's disease. Lancet 1994;344:714-17.

15 Goldberg YP, Kremer B, Andrew SE, et al. Molecular analysis of new mutations for Huntington's disease: intermediate alleles and sex of origin effects [comments]. Nat Genet 1993;5:174-9.

16 Myers RH, MacDonald ME, Koroshetz WJ, et al. De novo expansion of a (CAG)n repeat in sporadic Huntington's

17 Bozza A, Malagu S, Calzolari E, et al. Expansion of a (CAG)n repeat region in a sporadic case of HD. Acta Neurol Scand 1995;92:132-4.

18 Sanchez A, Rosich M, Castellvi-Bel S, et al. Sporadic Huntington's disease due to maternal transmission [abstract]. Am f Hum Genet 1995; (suppl 57):A227.

19 McGlennen RC, Allinson PS, Hagen VLM, et al. Evidence of an unstable paternal 27 CAG repeat allele in the Huntington gene giving rise to clinically overt Huntington disease in a patient with the genotype (17/38) [abstract]. Am f Hum Genet 1995;(suppl 57):A246.

20 Rubinsztein DC, Amos W, Leggo J, et al. Mutational bias provides a model for the evolution of Huntington's disease and predicts a general increase in disease prevalence. Nat Genet 1994;7:525-30.

21 Goldberg YP, McMurray CT, Zeisler J, et al. Increased instability of intermediate alleles in families with sporadic instability of intermediate alleles in families with sporadic Huntington's disease compared to similar sized intermediate alleles in

22 Leeflang EP, Zhang L, Tavare S, et al. Single sperm analysis of the trinucleotide repeats in the Huntington's disease gene: quantification of the mutation frequency spectrum. Hum Mol Genet 1995;4:1519-26.

23 Hanning VL, Vnencak-Jones CL, Kennedy JS, et al. Increased frequency of reduced penetrance Huntington disease alleles in later onset families, counselling dilemmas and use of positron emission tomography [abstract]. $A m \mathcal{F}$ Hum Genet 1997;61:A188.

24 Lathrop GM, Hooper AB, Huntsman JW, et al. Evaluating pedigree data. 1. The estimation of pedigree error in the presence of marking mistyping. Am f Hum Genet 1983;35: 241-62.

25 Kremer B, Squitieri F, Telenius $\mathrm{H}$, et al. Molecular analysis of late onset Huntington's disease. F Med Genet 1993;30: 991-5.

26 Myers RH, Sax DS, Schoenfeld M, et al. Late onset of Huntington's disease. 7 Neurol Neurosurg Psychiatry 1985; 48:530-4.

27 Britton JW, Uitti RJ, Ahlskog JE, et al. Hereditary late-onset chorea without significant dementia: genetic evidence for substantial phenotypic variation in Huntington's disease. Neurology 1995;45:443-7.

28 Nance MA. Huntington disease: another chapter rewritten. Am 7 Hum Genet 1996;59:1-6.

29 StClair D. Expanded CAG trinucleotide repeat of Huntington's disease gene in a patient with schizophrenia and a normal striatal histology. F Med Genet 1994;31:658-9.

30 Spector E, Taylor L, Roser K, et al. Variable phenotype and genomic instability in individuals with 36-39 CAG repeats in one Huntington

31 De Rooij KE, De Koning Gans PA, Losekoot M, et al. Borderline repeat expansion in Huntington's disease [letter]. Lancet 1993;342:1491-2.

32 Rubinsztein DC, Leggo J, Goodburn S, et al. Study of the Huntington's disease (HD) gene CAG repeats in schizophrenic patients shows overlap of the normal and HD affected ranges but absence of correlation with schizophrenia. 7 Med Genet 1994;31:690-3.

33 Andrew SE, Goldberg YP, Kremer B, et al. The relationship between trinucleotide (CAG) repeat length and clinical features of Huntington's disease [see comments]. Nat Genet 1993;4:398-403. 